\title{
Sistem Informasi Manajemen Lembaga Pendidikan dan Pelatihan Madani (LP2M) dengan Metode Extreme Programming
}

\author{
Mesri Silalahi ${ }^{1 *}$, Saut Pintubipar Saragih ${ }^{2 *}$ \\ * Sistem Informasi, Universitas Putera Batam \\ mesri@puterabatam.ac.id ${ }^{1}$,pipin.sitio@gmail.com ${ }^{2}$
}

\begin{tabular}{l} 
Article Info \\
\hline Article history: \\
Received 2019-10-11 \\
Revised 2019-11-07 \\
Accepted 2019-11-28 \\
\hline
\end{tabular}

Keyword:

Metode Extreme Programming, Sistem Informasi Manajemen, Website.

\begin{abstract}
Lembaga Pendidikan dan Pelatihan Madani (LP2M) merupakan suatu lembaga yang bergerak di bidang Pendidikan Non Formal. LP2M telah banyak melaksanakan kegiatan-kegiatan baik diklat-diklat singkat, bimtek, seminar dan lokakarya di bidang kedinasan dan kegiatan-kegiatan lainnya. Dalam pengelolaan berbagai kegiatan tersebut, saat ini dilakukan secara konvensional (manual) sedangkan dalam pengolahan data dilakukan dengan menggunakan Program Ms.Excel. Salah satu contoh yaitu dalam mencatat data-data pendaftaran maupun peserta pelatihan. Padahal kompleksitas data, integrasi, prosedur atau proses bisnis, dan pengendalian organisasi diperlukan adanya sistem informasi. Penelitian ini betujuan untuk merancang dan membangun sebuah sistem informasi online berupa website dengan menggunakan Metode Extreme Programming. Dengan metode tersebut maka perancangan akan lebih sederhana dan waktu akan lebih singkat. Hasil penelitian membahas terkait efektifitas dan efesiensi dari hasil perancangan sistem informasi manajemen LP2M.
\end{abstract}

Copyright (C) 2019 Journal of Applied Informatics and Computing. All rights reserved.

\section{Pendahuluan}

Sistem informasi merupakan salah satu hal penting yang wajib ada saat ini dalam sebuah organisasi seperti lembaga pendidikan maupun lembaga lainnya, hal ini dikarenakan banyaknya tuntutan dalam menyampaikan informasi yang harus cepat, tepat, akurat serta tepat waktu. Hal inilah yang mengakibatkan perlunya suatu alat-bantu yang dapat melakukan proses dengan cepat dan dengan risiko yang sangat kecil. Oleh karena itu banyak sekali organisasi yang memanfaatkan sistem informasi berbasis web karena dengan sistem ini masyarakat dapat dengan cepat, tepat dan akurat memperoleh informasi yang mereka butuhkan.

Lembaga Pendidikan dan Pelatihan Madani (LP2M) merupakan salah satu lembaga Pendidikan Non Formal yang memiliki kantor cabang di beberapa kota di Indonesia yaitu Jakarta dan Palembang. Sasaran pendidikan LP2M ditujukan bagi para pekerja dan profesional di instansi Pemerintah maupun swasta. LP2M telah banyak melaksanakan kegiatan yaitu diklat-diklat singkat, bimtek, seminar dan lokakarya di bidang kedinasan, bimtek pengadaan barang/jasa pemerintah dan ujian sertifikasi keahlian pengadaan barang/jasa, keuangan daerah, bimtek tipikor, kepabeanan, perpajakan, ketenagakerjaan, manajemen keamanan, pendidikan pramugari dan pramugara serta kegiatan-kegiatan lainnya yang dilaksanakan di Batam, Medan, Pekanbaru,
Palembang, Jakarta, Jambi, Lampung, Samarinda, Semarang, Yogjakarta dan beberapa kota lainnya di Indonesia. Kompleksitas data, integrasi, prosedur atau proses bisnis, dan pengendalian organisasi diperlukan adanya sistem informasi terintegrasi secara online [1].

Kegiatan di LP2M berawal dari pembuatan perencanaan oleh pimpinan yang kemudian membuka pendaftaran peserta pelatihan sesuai dengan kuota yang telah ditetapkan. Dalam proses penerimaan peserta, terdapat beberapa cara yang disediakan oleh LP2M yaitu pendaftaran melalui telepon dan, secara langsung mendaftar ke kantor LP2M. Pilihan lainnya dengan mendaftar online melaui website LKPP sebagai lembaga yang menaungi LP2M. Data para calon peserta yang mendaftar secara langsung ke situs LKPP ini nantinya akan di-record oleh staff LP2M dalam Ms.Excel. Hal ini dikarenakan sistem yang dipakai LP2M masih menggunakan Ms. Excel. Permasalahannya adalah walaupun peserta dapat mendaftar secara online ke website LKPP hal ini dirasa masih kurang efektif dikarenakan jarang sekali ada calon peserta yang melakukan pendaftaran ke situs tersebut dan apabila ada yang mendaftar ke website LKPP maka data-data peserta hanya ada di LKPP sedangkan LP2M harus mencatat kembali data-data tersebut ke file mereka sehingga staf LP2M harus meminta data tersebut kepada pihak LKPP. Proses ini memperlambat proses pengelolaan berbagai 
keperluan pelatihan. Hal-hal lain yang berhubungan dengan permasalahan ini yaitu para calon peserta kebanyakan kurang paham dengan pendaftaran melalui website LKPP sehingga bisa dipastikan untuk melakukan pendaftaran biasanya dilakukan lewat telpon dan mengisi formulir yang sudah disediakan.

Sebagai salah satu lembaga yang sudah telah memiliki beberapa cabang, direktur utama sebagai pimpinan dan sekaligus owner LP2M tentu jarang sekali berada di tempat, oleh karena itu apabila membutuhkan data-data dan informasi biasanya staf akan mengirimkan melalui email dan komunikasi dengan staf melalui telepon. Pimpinan tidak dapat segera memperoleh data-data dan informasi yang dibutuhkan. Hal ini dikarenakan sistem yang dipakai dalam pengelolaan berbagai kegiatan pelatihan masih menggunakan Ms. Excel. Ketika peserta telah selesai melakukan kegiatan pelatihan dan sertifikasi maka proses selanjutnya oleh staf LP2M yaitu menginput data-data peserta pelatihan dan sertifikasi yang diperoleh dari LKPP kedalam program Ms.Excel LP2M. Selanjutnya dalam pembuatan laporan dan berbagai hal yang ada di LP2M juga masih dilakukan dengan menggunakan Ms.Excel sehingga hal ini dapat mengakibatkan lambatnya melakukan berbagai kegiatan.

Sejalan dengan penelitian [2] yang menyebutkan bahwa dengan merancang sistem informasi manajemen berbasis web diharapkan dapat memberikan manfaat untuk semua kalangan. Selain itu juga penelitian [3], mengungkapkan dengan adanya sistem informasi administrasi berbasis web ini dapat memberikan kemudahan dan meminimalkan kesalahan yang terjadi pada bagian administrasi serta stakeholder yang terkait.

Penelitian ini mencoba membangun sistem informasi manajemen dengan model Extreme Programming (XP) yang dapat mengelola proses pendaftaran, pengelolaan kegiatan, serta pembuatan laporan-laporan oleh staff LP2M. Metode extreme programming mendorong pengembangan perangkat lunak yang praktis, interaksi yang singkat, jumlah tim sedikit [4]. Oleh karena itu penelitian akan mengimplementasikan dan membahas terkait efektifitas dan efesiensi dari hasil perancangan model extreme programming.

\section{Metode Penelitian}

Metode Extreme programming (XP) merupakan perangkat lunak yang berfungsi menekankan kualitas kode, yang pada kenyataannya dapat mengurangi motivasi pengembang untuk fokus pada masalah kegunaan [5]. XP mengeksploitasi pengurangan biaya perubahan persyaratan perangkat lunak. Berdasarkan temuan, praktik XP cocok untuk pengembangan perangkat lunak berskala besar yang kompleks [6] [7]. Untuk membangun tingkat keamanan yang dapat diterima dalam suatu sistem, setiap peran XP perlu mengadopsi praktik fokus keamanan sebagai prioritas untuk mengurangi ancaman atau kerentanan. Ilustrasi dari tahapan pelaksanaan penelitian [8] perancangan ini dapat dilihat pada metode penelitian sebagai berikut.

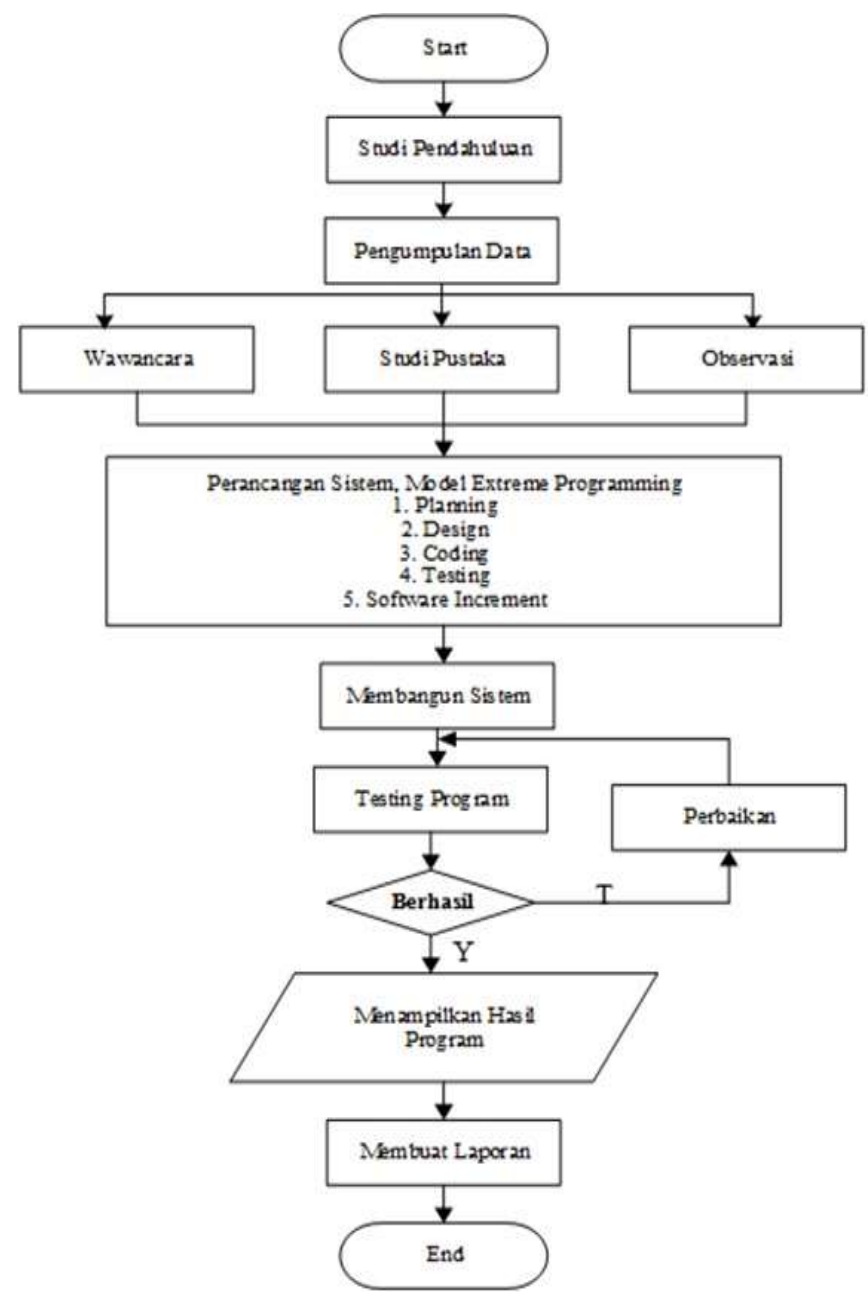

Gambar 1. Metode Penelitian

Gambar 1 menjelaskan tahapan yang dilakukan dalam penelitian dimulai dari studi pendahuluan untuk memahami permasalahan pada LP2M terkait sistem informasi manajemen. Langkah selanjutnya yaitu pengumpulan data yang dilakukan melalui wawancara, observasi dan studi pustaka. Berdasarkan data-data yang terkumpul kemudian dilakukan perancangan sistem dengan metode extreme programming dengan tahapan: perencanaan, design, coding, testing, software increment. Sistem yang sudah dirancang selanjutnya dibangun dan dilakukan testing, setelah sistem berhasil melakukan fungsi-fungsi yang sudah ditetapkan maka langkah terakhir yaitu peneliti menyusun laporan penelitian.

Lembaga Pendidikan dan Pelatihan Madani atau LP2M beralamat di Gedung A. Komplek Holliwod Hills Blok Jachy No.9 D-E-F Batam Center Kota Batam. Peneliti mengunjungi secara langsung LP2M dan bertemu dengan staff LP2M yang bertanggung jawab dalam pengelolaan LP2M. Teknik pengumpulan data lainnya yang dilakukan peneliti yaitu dengan melakukan wawancara dengan owner LP2M yang diwakilkan oleh staff penanggungjawab LP2M. 
Untuk menganalisis permasalahan yang ada maka dilakukan analisis SWOT dimana Analisis SWOT ini adalah sebuah bentuk analisis situasi dan kondisi yang bersifat deskriptif (memberi gambaran). Analisis ini menempatkan situasi dan kondisi sebagai faktor masukan, yang kemudian dikelompokkan menurut kontribusinya masing-masing. Analisis ini terbagi atas empat komponen dasar yaitu strength, weakness, opportunity dan threat.

Strength (S), adalah situasi atau kondisi yang merupakan kekuatan dari organisasi atau program pada saat ini. Strength pada penelitian, yaitu: Lembaga Pendidikan dan Pelatihan Madani sudah mempunyai beberapa cabang di beberapa kota di Indonesia. LP2M juga menawarkan berbagai program pelatihan, sehingga besar kemungkinan banyak calon peserta pelatihan yang mengikuti pelatihan dan sertifikasi melalui lembaga ini.

Weakness (W), adalah situasi atau kondisi yang merupakan kelemahan dari organisasi atau program pada saat ini. Weakness dari sistem yang sedang berjalan saat ini yaitu belum adanya sebuah sistem informasi yang mampu membantu staff dalam melakukan berbagai kegiatan pelatihan dan sertifikasi.

Opportunity (O), adalah situasi atau kondisi yang merupakan peluang diluar organisasi dan memberikan peluang berkembang bagi organisasi dimasa depan. Lembaga pendidikan dan pelatihan mempunyai peluang untuk berkembang pesat dikarenakan program yang mereka tawarkan cukup banyak dan sesuai dengan kebutuhan serta lokai pelaksanaan pelatihan dan sertifikasi yang sudah tersebar di beberapa kota di Indonesia.

Threat (T), adalah situasi yang merupakan ancaman bagi organisasi yang datang dari luar organisasi dan dapat mengancam eksistensi organisasi di masa depan. Beberapa hal yang menurut peneliti menjadi ancaraman bagi kemajuan LP2M yaitu munculnya berbagai lembaga yang bergerak di bidang yang sama sehingga jika LP2M tidak memberikan pelayanan khususnya dalam bentuk pemanfaatan teknologi informasi yang dapat mempermudah peserta maupun calon peserta pelatihan maka sangat besar kemungkinan akan kalah dari lembaga lain.

\section{Hasil Perancangan}

Hasil dari penelitian ini yaitu merancang dan membangun sistem informasi manajemen berbasis web pada LP2M sesuai dengan tahapan dalam metode XP menggunakan bahasa pemrograman PHP dan database MySQL [9] [10]. Hasil rancangan sistem dimulai dari membuat aliran sistem informasi, usecase diagram, activity diagram, Sequence diagram serta diagram-diagram lainnya sebagai berikut.

Gambar 2 (dilampiran) menjelaskan bagaimana aliran data dan informasi pada sistem informasi manajemen yang sudah dibangun pada LP2M. Sebelum sistem dibangun, terlebih dahulu dibuat flow map dari sistem yang akan dirancang, hal ini ditujukan untuk mempermudah dalam perancangan sistem.
Gambar 3 (dilampiran) usecase diagram menjelaskan tentang hubungan antar aktor pada sistem yang akan dibangun. Pada usecase ini ditetapkan 3 aktor yaitu staff LP2M, peserta, dan direktur.

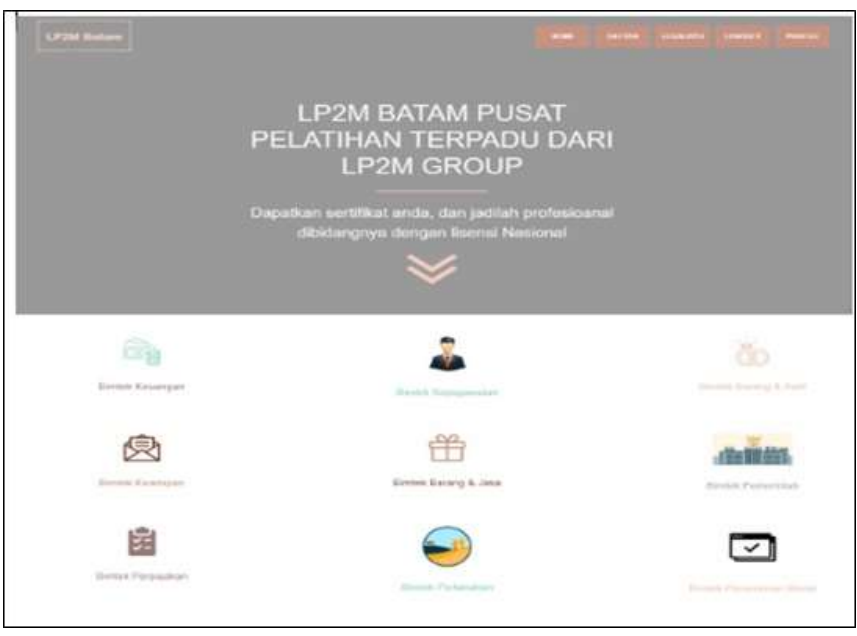

Gambar 4. Tampilan utama sistem

Gambar 4 merupakan tampilan utama dari sistem informasi manajemen LP2M yang telah dibangun. Pada tampilan utama sistem terdapat beberapa menu yang dapat diakses secara langsung oleh user tanpa harus melakukan login terlebih dahulu. Menu-menu tersebut yaitu berbagai pelatihan yang ditawarkan oleh LP2M, user dapat mencari berbagai informasi terkait dengan meng klik menu yang sudah ditampilkan. Pada tampilan utama ini juga disediakan menu login untuk user yang sudah diberikan hak akses, selain itu juga tersedia menu register.

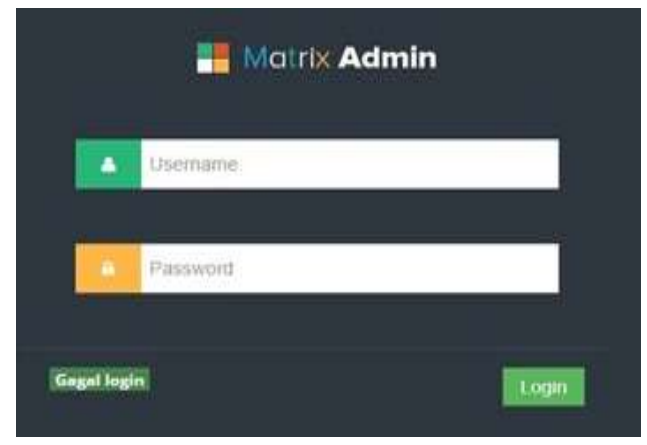

Gambar 5. Tampilan Form Login Sistem

Untuk login ke sistem informasi manajemen LP2M, user perlu masuk melalui menu login. Tampilan menu login seperti pada gambar 5. Menu ini dapat dipergunakan oleh user yang sudah melakukan registrasi terlebih dahulu. 


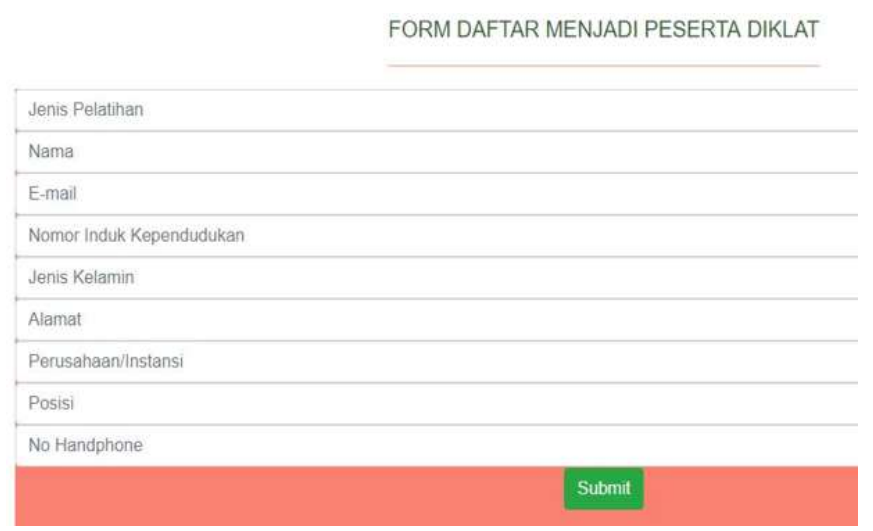

Gambar 6. Tampilan Form Pendaftaran

Gambar 6 menunjukkan tampilan form pendaftaran oleh calon peserta pelatihan yang sudah terlebih dahulu melakukan registrasi ke sistem.

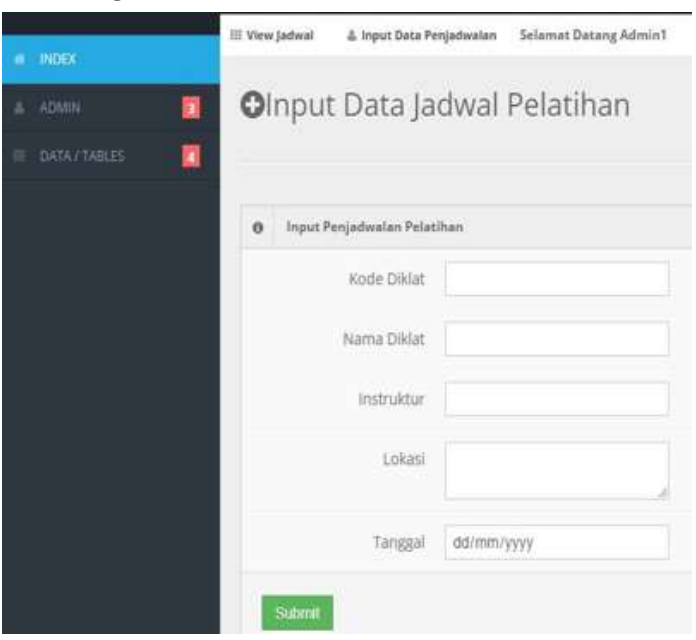

Gambar 7. Tampilan Form Input Data Jadwal pelatihan

Gambar 7 merupakan tampilan form input data jadwal pelatihan., form ini diisi oleh direktur dan kemudian akan ditindaklanjuti oleh bagian staff untuk membuat jadwal pelatihan secara rinci, jadwal pelatihan yang sudah dibuat secara rinci oleh bagian staff nantinya akan di publish di sistem.

\section{Diskusi dan Pembahasan}

Implementasi metode XP dalam perancangan sistem informasi manajemen LP2M yang baru mempunyai beberapa kelebihan salah satunya yaitu simplicity (kesederhanaan). XP melakukan semua pekerjaan dengan sederhana dan praktis tanpa mengurangi fungsi utamanya. Dalam membuat desain sitem informasi manajemen LP2M yang baru, bentuk simplicity (kesederhanaan) yang dilakukan yaitu menghilangkan fitur-fitur yang tidak ada gunanya atau menghapus fungsi yang tidak terpakai. Sistem dibuat sederhana sesuai kebutuhan sehingga tidak menimbulkan pemborosan dan akan dilakukan pengembangan nantinya jika diperlukan. Apabila dibandingkan sistem yang lama dengan sistem informasi LP2M yang baru dibangun maka dapat dapat dibuat perbandingan sebagai berikut.

TABEL 1

PERBANDINGAN SISTEM

\begin{tabular}{|c|c|c|}
\hline No & Sistem Lama & Sistem Baru \\
\hline 1 & $\begin{array}{l}\text { Tidak terdapat menu untuk } \\
\text { pendaftaran peserta } \\
\text { pelatihan dan sertifikasi }\end{array}$ & $\begin{array}{l}\text { Terdapat pencatatan menu } \\
\text { untuk pendaftaran peserta } \\
\text { pelatihan dan sertifikasi }\end{array}$ \\
\hline 2 & $\begin{array}{l}\text { Tidak terdapat jadwal } \\
\text { pelatihan dan sertifikasi }\end{array}$ & $\begin{array}{l}\text { Terdapat pencatatan pelatihan } \\
\text { dan sertifikasi }\end{array}$ \\
\hline 3 & $\begin{array}{lr}\text { Tidak } & \text { terdapat menu } \\
\text { laporan } & \text { pelaksanaan } \\
\text { kegiatan } & \\
\end{array}$ & $\begin{array}{l}\text { Terdapat menu laporan } \\
\text { pelaksanaan kegiatan }\end{array}$ \\
\hline 4 & $\begin{array}{l}\text { User tidak dapat melihat } \\
\text { informasi jadwal rinci } \\
\text { peserta pelatihan dan } \\
\text { sertifikasi }\end{array}$ & $\begin{array}{l}\text { User dapat melihat informasi } \\
\text { jadwal rinci peserta pelatihan } \\
\text { dan sertifikasi }\end{array}$ \\
\hline
\end{tabular}

Beberapa keunggulan dalam segi efisiensi dengan diimplementasikannya sistem yang baru, antara lain:

- Calon peserta pelatihan dan sertifikasi pada LP2M dapat melakukan pendaftaran secara online.

- Calon peserta pelatihan dan sertifikasi pada LP2M dapat langsung mengirimkan bukti pembayaran pendaftaran secara online

- Calon peserta pelatihan dan sertifikasi pada LP2M dapat melakukan melihat berbagai informasi melalui sistem yang baru, mulai dari informasi jadwal pelatihan, jadwal rinci pelaksanaan kegiatan pelatihan dan sertifikasi, hasil pelaksanaan kegiatan yaitu lulus atau gagal.

- Direktur dapat melihat laporan pelaksaaan kegiatan secara online.

Dari segi efektivitas, terdapat beberapa keunggulan diimplementasikannya sistem yang baru, antara lain:

- Dengan adanya sistem informasi yang baru maka direktur dapat mengelola perusahaannya dengan cepat.

- Staff LP2M dapat bekerja lebih cepat sehingga dapat menghemat biaya untuk lembur karyawan.

- Dengan adanya sistem yang baru dapat mempermudah pimpinan sebagai pemilik dalam pengambilan keputusan.

\section{KESIMPULAN}

Berdasarkan penelitian yang dilakukan dapat disimpulkan bahwa sistem informasi manajemen LP2M yang telah dibangun dengan manganalisa SWOT dapat memudahkan dalam memetakan sistem yang berjalan dengan sistem baru yang akan dikembangkan. Sistem yang telah dibangun dibandingkan dan melihat dari segi efisiensi dan efektifitas diperoleh kemudahan dalam pengelolaan dan manajemen prosedur / proses bisnis sehingga menguntungkan berbagai pihak termasuk pihak pimpinan dalam mengelola perusahaannya, selain itu staff yang bertugas juga semakin lebih mudah dan cepat dalam melakukan berbagai kegiatan. Sistem informasi manajemen pelatihan pada LP2M, yang 
telah diimplementasikan menggunakan metode XP dapat meningkatkan efisiensi dan efektivitas dalam perancangan sistem.

\section{UCAPAN TERIMA KASIH}

Terimakasih kepada Universitas Putera Batam yang telah mendukung terlaksananya penelitian ini mulai dari awal hingga selesai, ucapan terimakasih juga penulis sampaikan kepada pihak LP2M yang telah meluangkan waktu dalam proses penelitian ini.

\section{DAFTAR PUSTAKA}

[1] D. E. Kurniawan, A. Saputra, P. Prasetyawan, and others, 'Perancangan Sistem Terintegrasi pada Aplikasi Siklus Akuntansi dengan Evaluasi Technology Acceptance Model (TAM)', J. RESTI (Rekayasa Sist. dan Teknol. Informasi), vol. 2, no. 1, pp. 315-321, 2018.

[2] Y. B and R. R. Nurdin, "Yusran B., 2) Ririn Rahmadani Nurdin," J. Teknosains, vol. 10, no. 2, pp. 149-164, 2016.

[3] H. M. Susanto, W. Mantja, I. Bafadal, and A. Sonhadji, "Analisis Dan Perancangan Sistem Informasi Manajemen Kepegawaian ( SIMPEG ) Pada Badan Kepegawaian Pendahuluan Landasan Teori Analisis," J. Pendidik. Hum., vol. 3, no. 2, pp. 93-105, 2015.

[4] R. A. Azdy and A. Rini, "Penerapan Extreme Programming Dalam Membangun Aplikasi Pengaduan Layanan Pelanggan ( Palapa ) Pada Perguruan Tinggi," $J$. Teknol. Inf. dan Ilmu Komput., vol. 5, no. 2, pp. 197-206, 2018.

[4] A. Fatoni and D. Dwi, "Rancang Bangun Sistem Extreme Programming Sebagai Metodologi Pengembangan Sistem," Prosisko, vol. 3, no. 1, pp. 1-4, 2016.

[5] O. Sohaib and K. Khan, "Integrating Usability Engineering and Agile Software Development," Int. Conf. Comput. Des. Appliations, vol. 2, no. Iccda, pp. 32-38, 2010.

[6] I. Ghani, N. Izzaty, and A. Firdaus, "Role-Based Extreme Programming (Xp) for Secure Software Development," Malaysia Sci.Int.(Lahore), vol. 25, no. 4, pp. 1071-74, 2013.

[7] R. Fojtik, "Extreme programming in development of specific software," Procedia Comput. Sci., vol. 3, pp. 1464-1468, 2011.

[8] L. Lei and P. Wen-li, "Research on Design Information Management System for Leather Goods," Int. Conf. Appl. Phys. Ind. Eng., vol. 24, pp. 2151-2158, 2012.

[9] Dhining, Y. Rokhayati, D. E. Kurniawan, and others, 'Penerapan Replikasi Data pada Aplikasi Ticketing Menggunakan Slony PostgreSQL', J. Appl. Informatics Comput., vol. 1, no. 2, pp. 9-18, 2017.

[10] A. Prasetyo, "Strategi Perencanaan Sistem Informasi Dan Teknologi Informasi Di Lingkungan Perguruan Tinggi”, J. Appl. Informatics Comput., vol. 2, no. 2, pp. 24-28, Dec. 2018.. 
Flow Map Sistem yang baru

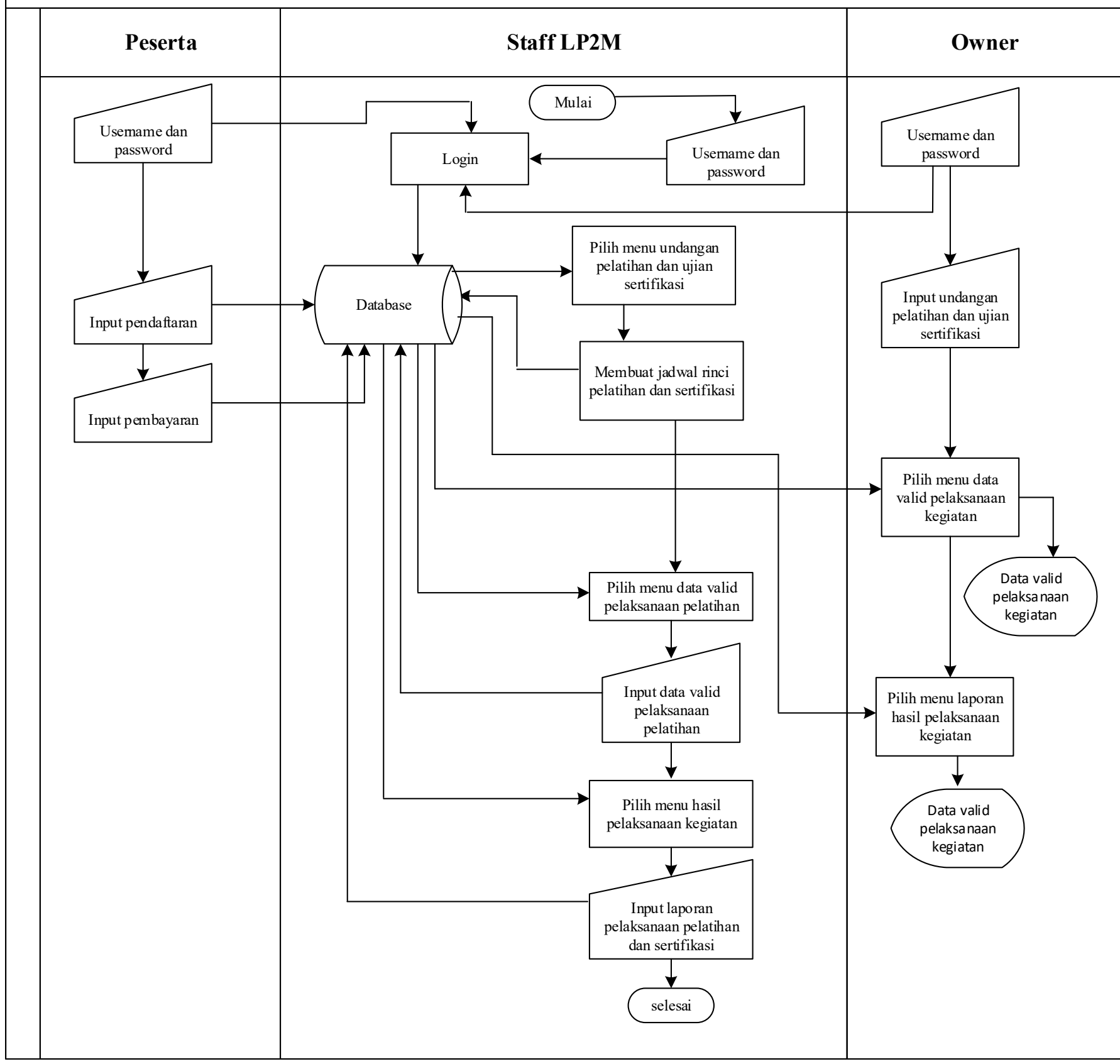

Gambar 1. Flow map sistem yang baru 


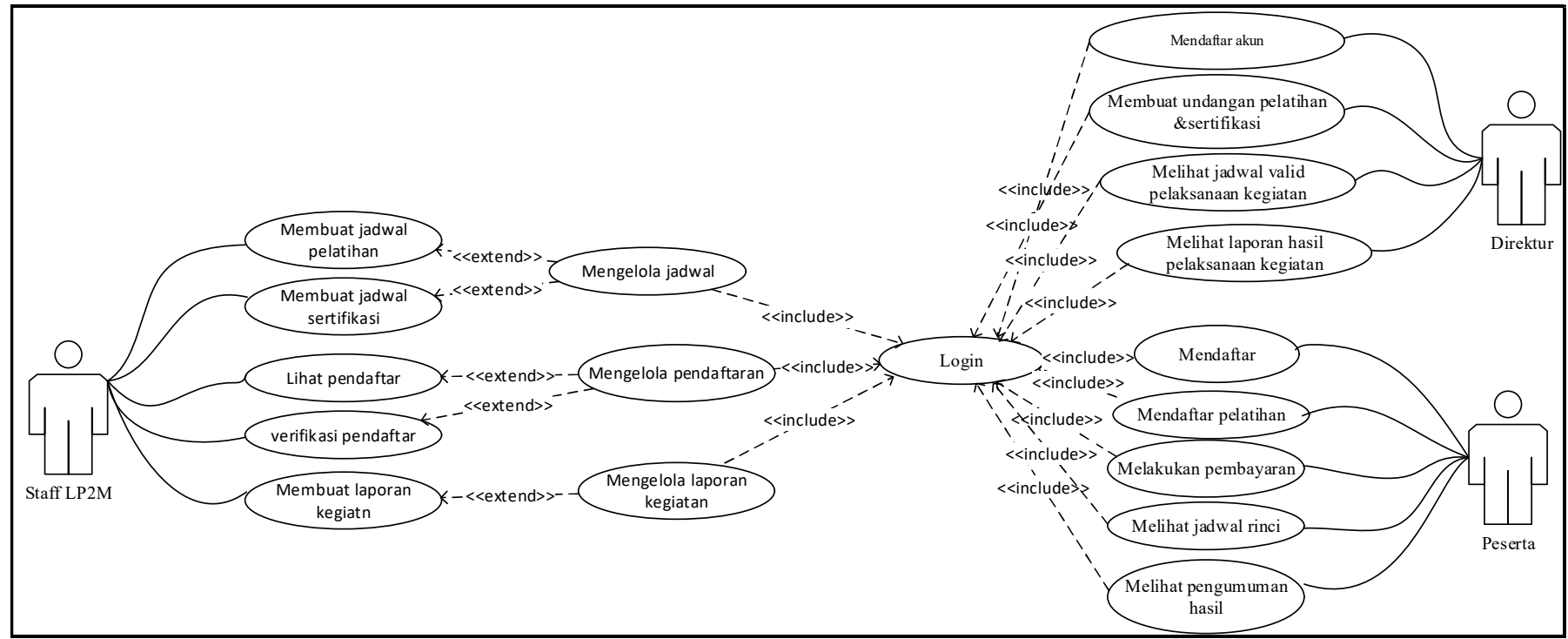

Gambar 2. Use case Diagram dan Class Diagram

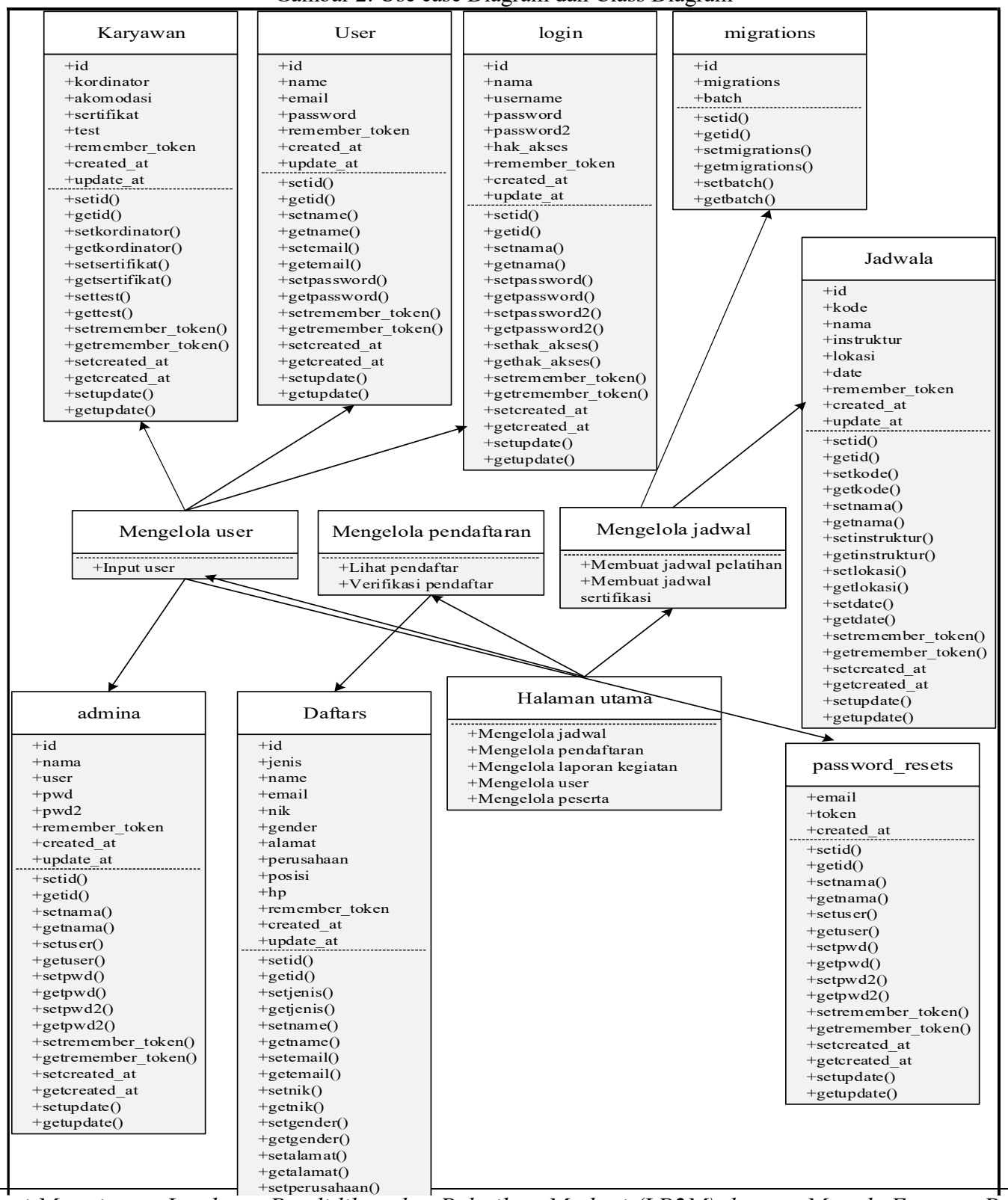

